uscript. Cognitive, interpretative, magical, historical functions are associated with different genre forms, both book and folk. Particularly considered is the «apocryphal riddle» of two brothers from the manuscript of the XVI ${ }^{\text {th }}$ century Stockholm Royal Library and manuscripts of the XVIII ${ }^{\text {th }}$ century collections of the Library of the Russian Academy of Sciences (St. Petersburg).

Keywords: ancient Slavic apocrypha, literary function

\title{
Татьяна Рождественская
}

DOI: $10.31168 / 91674-576-4.28$

Санкт-Петербургский государственный университет, Россия tat.rozhd@gmail.com

\section{Литургический текст}

\section{в памятниках эпиграфики Древней Руси}

В докладе в лингвистическом аспекте анализируются библейские и литургические цитаты в составе надписей-граффити XII-XV вв. из храмов Древней Руси. Показания палеографии, орфографии и текстологии характеризуют эти надписи как тексты, отражающие как нормы церковнославянского языка на Руси и его региональные варианты, так и черты, связанные с устной формой их бытования.

Ключевые слова: средневековые библейские и литургические надписи-граффити на стенах храмов Древней Руси, устная форма бытования канонических текстов

1. Литургические и богослужебные тексты Древней Руси, имеющие разветвленную рукописную традицию и составлявшие основной корпус книжности Slavia Orthodoxa, частично бытовали и в устном виде, могли воспроизводиться по памяти на церковных стенах. Библейские, литургические, гимнографические 
цитаты на стенах храмов как в составе росписей мастеров-живописцев, так и в личных записях-граффти священнослужителей и простых прихожан, их молитвенные возгласы и автографы так или иначе инициированы литургической традицией. Устный этап бытования канонических текстов приводил к вариативности отдельных языковых форм или графико-орфографических приемов. Структурная схема литургического текста включает как формулы традиционного языка, так и варьируемые элементы. Если лексические варианты в эпиграфических текстах связаны, как правило, с письменными языковыми и текстологическими традициями, то сфера графики, орфографии и морфологии допускает некоторый набор вариантов, хотя и ограниченных рядом семантических и грамматических параметров. Изучение богослужебных граффити связано с вопросами функционирования славянских библейских переводов и литургического церковнославянского языка. Привлечение к исследованию эпиграфического материала позволяет поставить вопросы о том, каковы были языковые и текстовые предпочтения в той или иной местной традиции, каковы пределы варьирования книжной языковой нормы в эпиграфических текстах и ряд других.

2. В докладе рассматриваются литургические надписи-граффити XII - XV вв., обнаруженные на стенах древнерусских храмов Киева [Корніенко 2010: 112-113, 42-43; Рождественская 2012: 317-325], Новгорода [Рождественская 1992: 114-115; Рождественская 2016: $193-$ 205; Гиппиус 2017: 261-282], Старой Ладоги [Рождественская 1992: 116-117]. Местонахождение литургических граффити - стены, столбы и дьяконник в храмах с сохранившимися участками древней штукатурки и фрескового слоя. Большинство граффити - это цитаты фрагментов великопостных служб, стихир и тропарей. Среди них - фрагменты Херувимской песни, прокимнов, инципиты ирмосов, строки великопостной 
службы Шестого часа, службы на Успение пресвятой Богородицы, строки запричастного стиха, фрагменты службы на Усекновение главы Иоанна Предтечи, священнических возгласов службы Всенощного бдения, стихира и тропарь утрени Великого Пятка и др. Особый комплекс таких текстов обнаружен в церкви Успения на Волотовом поле в Великом Новгороде. Палеографические, графико-орфографические и текстологические характеристики этих литургических цитат датируют их в пределах XV в. и отражают черты правленных редакций богослужебных книг, что является важным свидетельством времени их распространения в приходской практике средневекового Новгорода [Афанасьева 2015: 273-287].

\section{Литература}

Афанасьева 2015 - Афанасьева Т.И. Литургии Иоанна Златоуста и Василия Великого в рукописной традиции (по служебникам XI-XV вв.). М., 2015.

Гипnиус 2017 - Гиппиус А.А. «Зло видучи, а добра не видучи»: поэтика и грамматика древнейшего русского покаянного стиха // Russian Linguistics. T. 41. 2017. С. 261-282.

Корніенко 2010 - Корніенко В.В. Корпус графіті Софії Кивїської (XI - початок XVIII ст.) Ч. 1.: Приділ св. Георгія Великомученика. Київ, 2010.

Рождественская 1992 - Рождественская Т.В. Древнерусские надписи на стенах храмов. Новые источники XI-XV вв. СПб., 1992.

Рождественская 2016 - Рождественская Т.В. Средневековые граффити в церкви Успения пресв. Богородицы на Волотовом поле в Новгороде. В кн.: Да веселитс^ Новъградъ. Må Novgorod fröjda sig Hyllningsskrift till Elisabeth Löfstrand redigerad av Per Ambrosiani, Per-Arne Bodin och Nadezjda Zorikhina-Nilsson. Stockholms Universitet. Stockholm Slavic Papers. 2016. 


\section{Tatyana Rozhdestvenskaya}

Saint Petersburg State University, Russia

tat.rozhd@gmail.com

\section{Liturgical text in the Epigraphy of Old Rus'}

The paper analyses the linguistic aspect of biblical and liturgical quotations in the wall-inscriptions (graffiti) of the $12^{\text {th }}-15^{\text {th }}$ centuries in the Churches of Old Rus'. Paleografic, orthographic and textual features of the liturgical graffiti characterize them as texts, reflecting both the norms of the Church Slavonic language in Russia and its regional variants, as well as features associated with the oral form of their existence.

Keywords: medieval biblical and liturgical church wall-inscriptions Old Rus', the oral stage of the existence of canonical texts

\section{Франческа Ромоли}

DOI: $10.31168 / 91674-576-4.29$

Университет г. Пизы, Италия

francesca.romoli@unipi.it

\section{Житие Антония Римлянина: от местного к общему}

Доклад посвящен исследованию Жития Антония Римлянина в контексте средневековой восточнославянской агиографической традиции. Исследование проводится на уровне морфологии текста, метода его создания, идеологического замысла, культурно-исторических условий его появления и последующего развития.

Ключевые слова: Антоний Римлянин, церковнославянская литература, восточнославянская агиография.

Житие Антония Римлянина сохранилось в рукописях в двух вариантах единственной редакции. Первый вари- 